University of Nebraska - Lincoln

DigitalCommons@University of Nebraska - Lincoln

Agronomy \& Horticulture -- Faculty Publications

Agronomy and Horticulture Department

3-1935

\title{
Relation of Root Distribution to Organic Matter in Prairie Soil
}

J. E. Weaver

University of Nebraska-Lincoln

V. H. Hougen

M. D. Weldon

Follow this and additional works at: https://digitalcommons.unl.edu/agronomyfacpub

Part of the Plant Sciences Commons

Weaver, J. E.; Hougen, V. H.; and Weldon, M. D., "Relation of Root Distribution to Organic Matter in Prairie Soil" (1935). Agronomy \& Horticulture -- Faculty Publications. 449.

https://digitalcommons.unl.edu/agronomyfacpub/449

This Article is brought to you for free and open access by the Agronomy and Horticulture Department at DigitalCommons@University of Nebraska - Lincoln. It has been accepted for inclusion in Agronomy \& Horticulture -Faculty Publications by an authorized administrator of DigitalCommons@University of Nebraska - Lincoln. 


\section{THE}

\section{BOTANICAL GAZETTE}

\section{March 1935}

\section{RELATION OF ROOT DISTRIBUTION TO ORGANIC MATTER IN PRAIRIE SOIL ${ }^{\mathrm{I}}$}

J. E. WeAver, ${ }^{2}$ V. H. Hougen, ${ }^{2}$ AND M. D. WELDON

(WITH ELEVEN FIGURES)

\section{Introduction}

Although the root distribution of the chief grasses and forbs of tall-grass prairie has been known for I 5 years (18), no studies on the relation of root distribution to the organic matter in the soil have been made. In fact, so far as the writers are aware, few studies of this type have been undertaken in America. SpRague (I5), working in New Jersey, has attempted to correlate root occupation of the several soil layers with their specific soil properties. The grasses, chiefly Kentucky bluegrass and Colonial bent grass, were grown on a formerly cultivated soil of the gray-brown forest soil group of the humid eastern states. Practically all of the roots were found in the upper 9 inches of soil, the abundance decreasing rapidly with depth. He found no correlation between root distribution and organic carbon content of the soil.

During the late fall of 1932 , the writers selected a representative square meter of typical grassland in each of the two most important types or consociations of tall-grass prairie. The soil was removed to the depth of penetration of the grasses for the purpose of determining the relation of root distribution to the organic matter in prairie soil.

I Contribution from the Department of Botany, University of Nebraska, no. 87 .

2 Department of Botany.

3 Department of Agronomy. 
The roots were separated from the soil and the organic matter in both roots and soil in the several soil levels was determined.

\section{Stations}

Little bluestem (Andropogon scoparius) and big bluestem (A. furcatus) are the most important two of the six grassland types occurring in the eastern one-third of Nebraska and the western onethird of Iowa, but also including large areas in Kansas, Missouri, Minnesota, and South Dakota (I9). These two consociations constitute fully 80 per cent of the tall-grass prairie of this region. Because of their importance, the. stations were selected in these types.

A tract of $\mathrm{I} 20$ acres of upland prairie dominated by little bluestem and known as the Belmont prairie lies one mile north of Lincoln. The vegetation has been thoroughly studied and continuous records of the environmental factors during the growing season have been obtained over a period of I 5 years (20).

An area of about 40 acres of nearly pure big bluestem prairie is located on the floodplain of the Missouri River near Union, about 40 miles east of Lincoln, Nebraska. This prairie, owned by Mr. George Everett, was selected as representative of the Andropogon furcatus consociation and carefully studied $(7, \mathbf{1 9})$.

\section{Vegetation}

The Belmont prairie covers rolling hills. Little bluestem constitutes about 6o per cent of the vegetation; needle grass (Stipa spartea), June grass (Koeleria cristata), and prairie drop seed (Sporobolus heterolepis) are other common bunch grasses. Big bluestem and Indian grass (Sorghastrum nutans) are important sod-forming species as is also Kentucky bluegrass (Poa pratensis) (fig. I). Scribner's panic grass (Panicum scribnerianum) and Wilcox's panic grass (P. wilcoxianum) are common interstitial species. The basal or ground cover is about I 5 per cent, although the foliage cover, which varies greatly from year to year and with the progress of the season, is usually between 75 and roo per cent (fig. 2). Although the abundant forbs often form extensive societies, the grasses are everywhere the dominant species. In some local areas forbs are sparingly represented. 

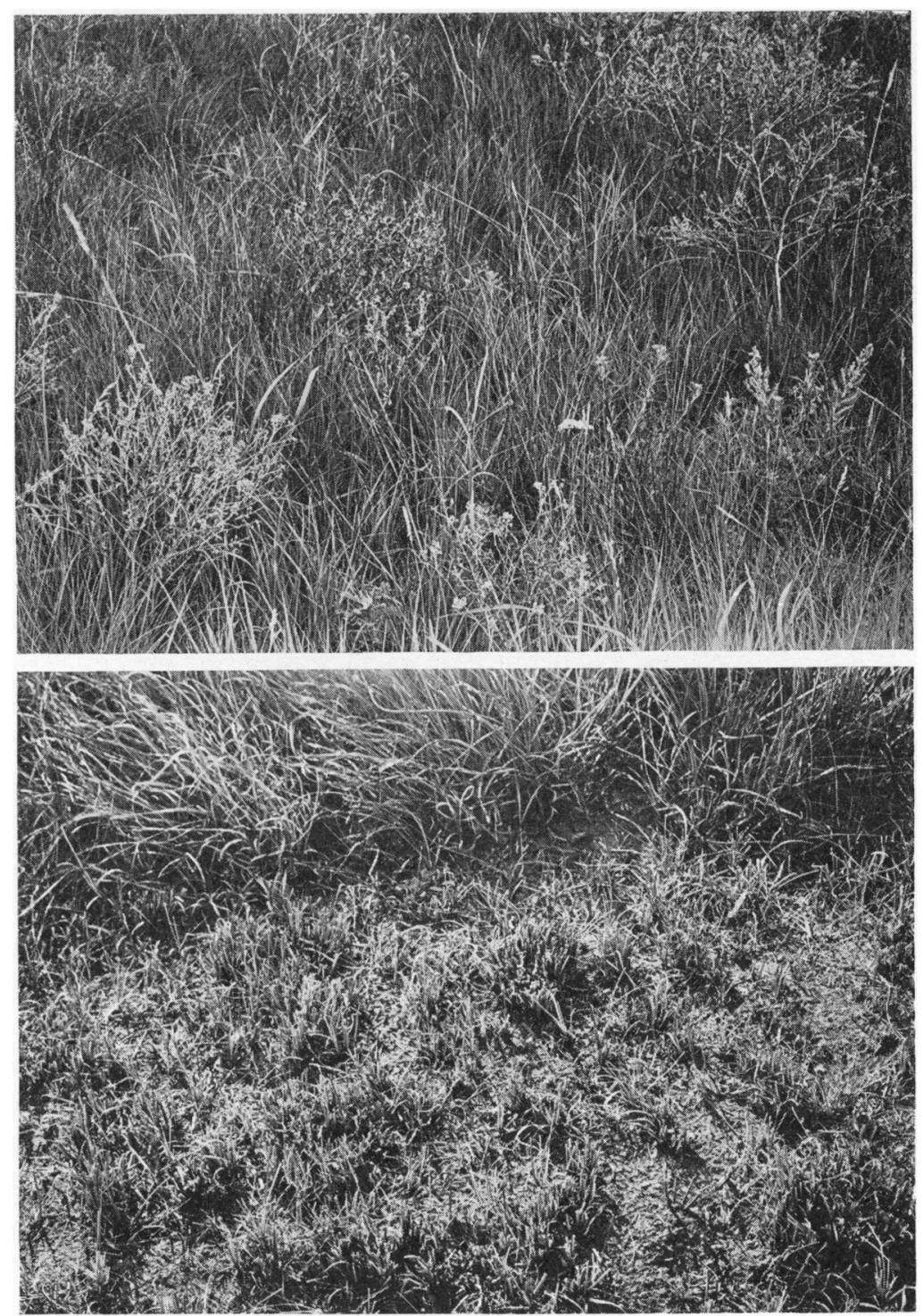

Figs. I, 2.-Fig. I (above), view in the Andropogon scoparius type of grassland late in June. Grass is about 15 inches high and Psoralea floribunda about 30 inches. Fig. 2 (below), detail of basal cover in upland prairie. Bunches of little bluestem have been cut and reveal about 85 per cent soil surface. 
The Everett prairie occurs on nearly level, well drained land lying between the Missouri River and its western bluff (fig. 3). Big bluestem alone constitutes 85 to 90 per cent of the vegetation. The chief accompanying grasses are Indian grass (Sorghastrum nutans), tall panic grass (Panicum virgatum), and relict slough grass (Spartina michauxiana). As a result of continued annual mowing, bluegrass has invaded but only in relatively small amounts. These sod-forming grasses, with a sprinkling of forbs, form a tall, dense foliage cover although the basal cover is only about I 2 per cent (fig. 4).

\section{Growth}

Growth of vegetation on both upland and lowland prairie is normally renewed about the middle of April, although certain species are somewhat earlier. Perhaps only 2 per cent of the vegetation consists of annual plants. The abundant accumulations of reserve foods in the underground parts of the perennials permit rapid development with the occurrence of warm weather in spring. Little bluestem attains a height of 3 to 4 inches early in May and a general level of about 18 inches late in July. The flower stalks then elongate rapidly and reach a height of 2 to 2.5 feet. FLORY (6) has determined its average percentage of growth by weight during a period of 3 years as follows: 2 per cent in April, 28 in May, 36 in June, and 21 in July. By the end of July it had practically completed vegetative growth and had the greatest functional surface of leaves. The I 2 per cent of growth in August and the I per cent in September consisted almost entirely of flower-stalk production.

The roots of the little bluestem reach a depth of about 4 feet. The extent of deterioration of the old root system each year and the rate of its replacement as well as the addition of more roots are as yet unsolved problems. It is known, however, that an entirely new root system may develop to the usual depth in a single summer if a block of sod is transplanted (4). Upland grasses and forbs in general grow more slowly than do those of lowlands and they are of smaller stature.

Growth in the low prairie is rapid. Big bluestem, the most important dominant, elongates at a maximum rate of nearly $2 \mathrm{~cm}$. per day, and like the other tall grasses completes its vegetative growth 

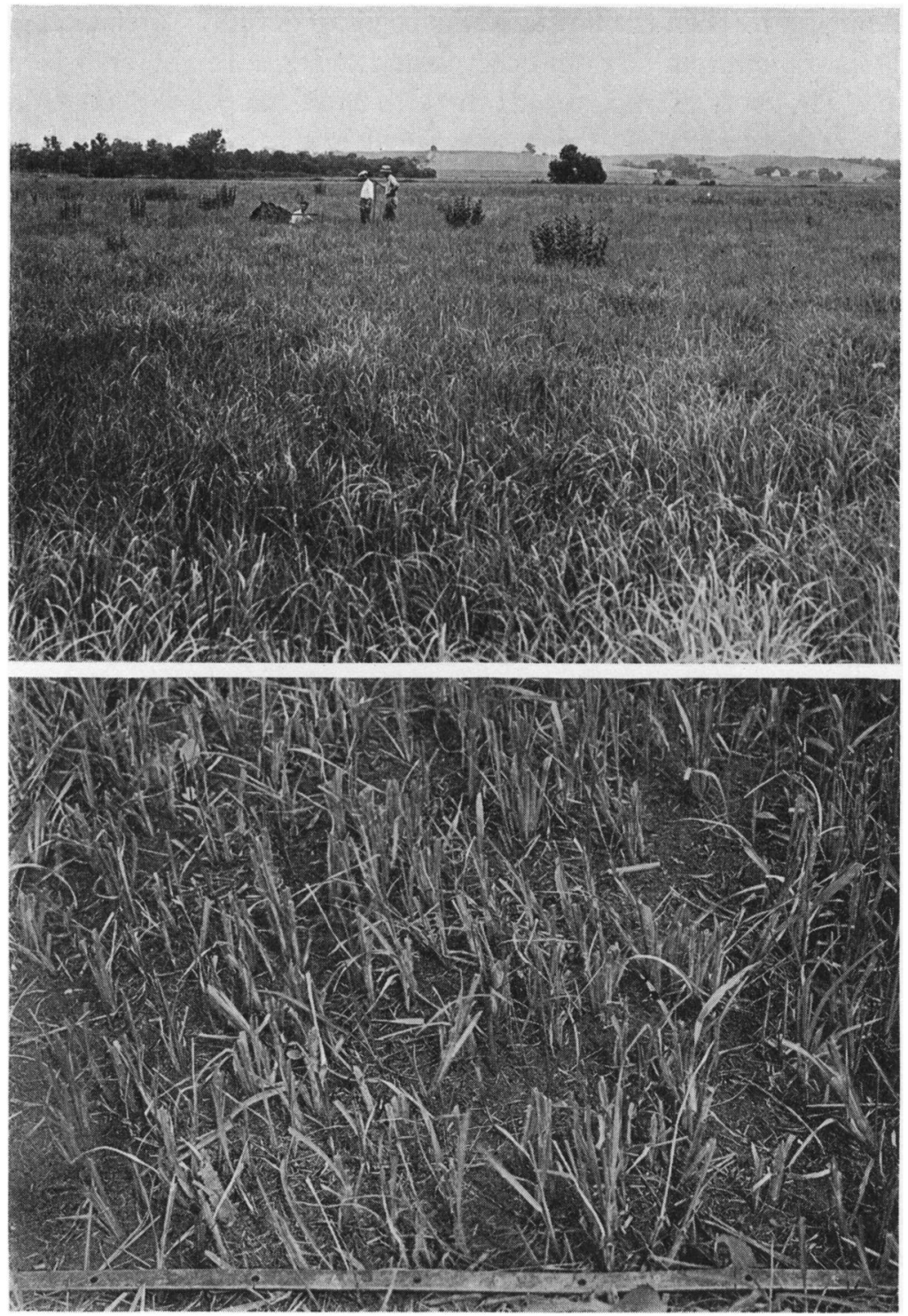

Figs. 3, 4.-Fig. 3 (above), general view of Everett prairie late in June. Grass is Andropogon furcatus and coarse herb, Silphium integrifolium. Fig. 4 (below), basal cover of a practically pure stand of $A$. furcatus on low prairie near Union, Nebraska. Plants cut and photographed late in June. 
The extracts were invariably yellowish brown in color and this method of preparing the standard solution facilitated the making of color comparisons.

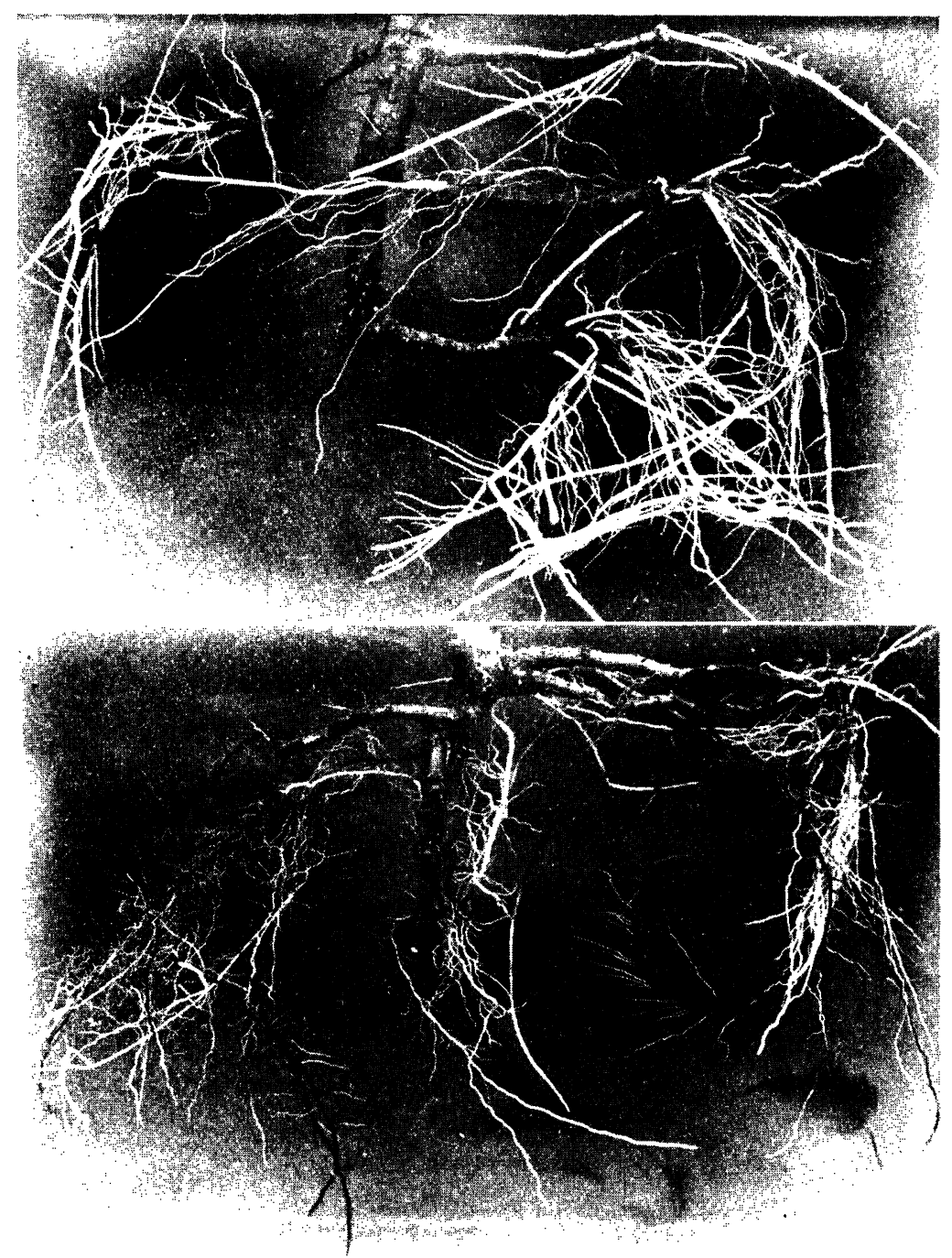

Fig. 2.-Peach roots March I 7. Upper illustration, $65^{\circ}$ : current roots more extensive but similar in quality to those at $55^{\circ}$; lower illustration, $75^{\circ}:$ note dead cortex and fine laterals. These roots lacked succulence. 
The usual microchemical methods (9) were followed and the reagents and range indicator method described by Small (27) were used in determining the $\mathrm{pH}$ values of various plant tissues.

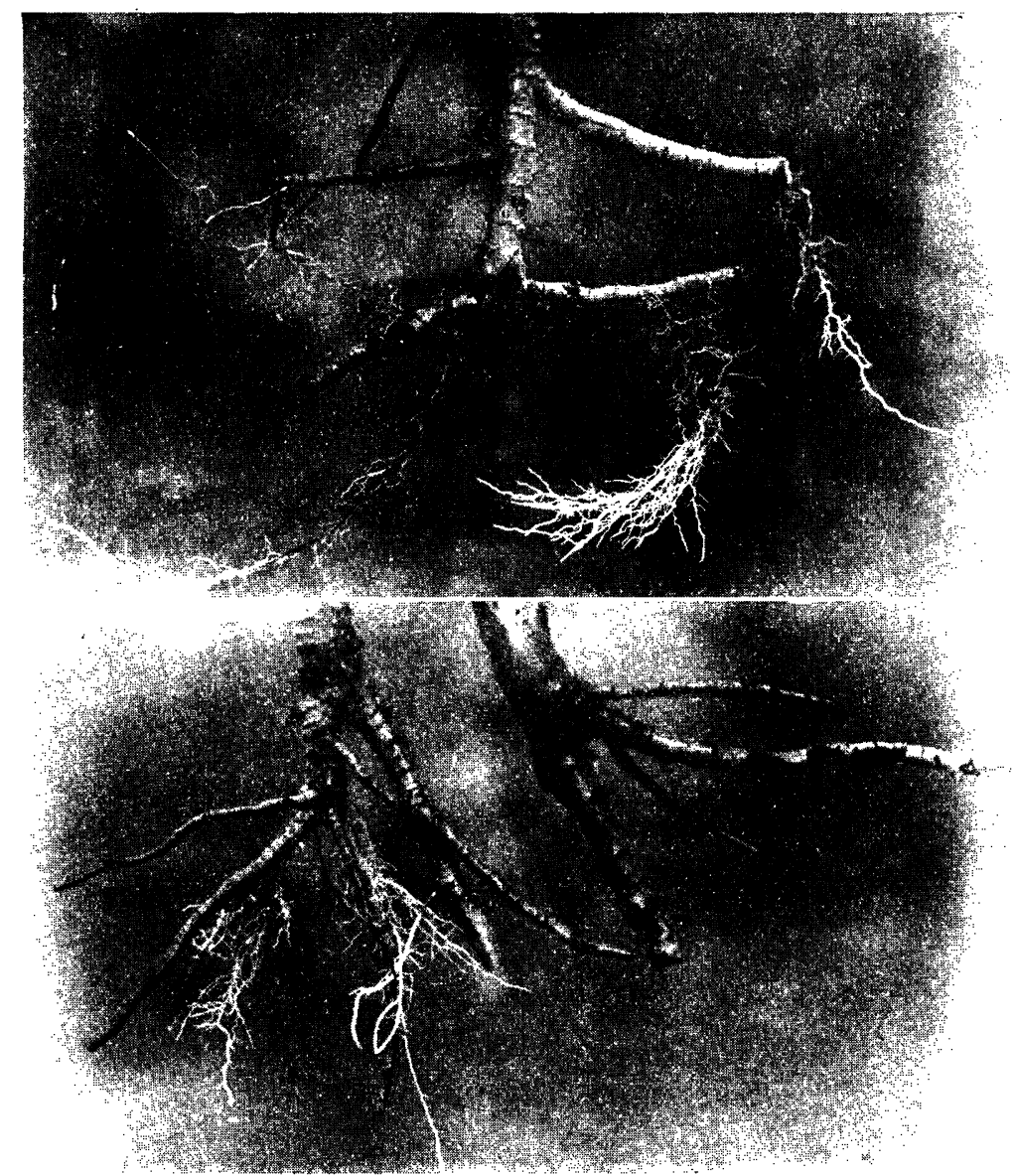

FIG. 3.-Peach roots March I 7. Upper illustration, $85^{\circ}$ : limited development of non-succulent current roots of very small diameter with short-lived cortex and numerous fine laterals; lower left, $90^{\circ}$ : roots much like those at $85^{\circ}$ but less extensive; lower right, $95^{\circ}$ : no new roots developed.

In preparing permanent slides, already well recognized methods were employed that need not be described in detail. Material was fixed in Navashin's solution, dehydrated, imbedded in paraffin, sec- 
average daily evaporation rate was considerably less in the lowland prairie at Union, as was also the wind movement.

\section{Soils}

The soil at the Belmont station is Lancaster loam, a mature upland soil of rolling topography derived from the Dakota sandstone formation. The samples were taken from a gentle north slope. The $A$ horizon extends to a depth of about 16 inches; the $B$ horizon lies between 18 and 30 inches; and the $C$ horizon extends far beyond the range of penetration of the roots of the grasses. The surface soil is a very dark grayish brown loam about $\mathrm{I} 2$ inches in depth, thoroughly interlaced with grass roots, well supplied with organic matter, and has a highly developed fine granular structure. It contains noticeable amounts of medium and fine sand and is very friable. The soil at $\mathrm{I} 2$ to $\mathrm{r} 6$ inches forms a transition layer, grayish brown in color, friable, increasing in compactness, clay content, and size of structural aggregates, the latter grading up to 4 or $5 \mathrm{~mm}$. in size. Below this is the horizon of clay accumulation which extends to a depth of 30 inches. It is friable, light grayish brown in color, and shows occasional rusty brown iron stains. Grass roots are numerous but small. The texture becomes much more sandy from the 30 -inch depth to about 42 inches. There is little change in color except that rust stains and chalky spots are numerous. At the 42 - to 44 -inch level the sand is entirely rust-brown in color. Below this it is light grayish brown and is compact and cemented.

The soil of the Everett prairie is mapped as Wabash silt loam, a type frequently found in the bottomlands of eastern Nebraska. It is described as a dark grayish brown or dark brown to black, heavy, smooth silt loam, having an average depth of 24 inches, underlain by a more compact silt loam which is usually somewhat lighter in color (8). It is alluvial in origin; the topography is flat and the drainage was originally poor, but has been greatly improved by cleaning the drainage channels and constructing roads and ditches. Before the land was settled it was undoubtedly subject to frequent inundations by surface run-off from the higher land, and has been inundated, once to a depth of several feet, within the past 50 years. Mr. Everett has owned this prairie for more than 50 years and has seen 
the vegetation gradually change, as the result of improved drainage conditions, from slough grass to big bluestem.

The profile examined was found to have a surface horizon, about 6 inches in depth, of dark grayish brown clay loam having a fine granular structure owing to the action of the fibrous grass roots with which this layer is heavily interspersed. Although this soil is mapped as silt loam, the high hygroscopic coefficients (I8.2 and I9.7 for the first and second 6 inches respectively) indicate it to be much heavier in texture. It is a heavy clay loam. The 6- to I 2 -inch layer is less granular, lighter in color, and much lower in organic matter than the surface 6 inches. At the depth of 12 inches there is a layer one-eighth to one-fourth inch thick of very light grayish brown material, sandier than the deposits above and below.

At the depth of 12 to 24 inches there is a horizon whose nearly black color, highly developed fine granular structure, and comparatively great thickness indicate that it was formerly the surface soil for a long period of time. It has the morphological characteristics of a surface soil more fully developed than has the present surface foot. The physical and chemical analyses confirmed this field observation. Compared with the 6- to I 2 -inch horizon, the second foot was found to have smaller volume-weight and specific gravity and greater pore space, organic matter, and nitrogen content. The hygroscopic coefficient, I 5.6, indicates it to be somewhat less heavy in texture than the surface layers. It is believed that many decades have elapsed since it was first covered with the present surface soil.

Between 24 and 28 inches there is a transition to a zone of light grayish brown soil which extends from 28 to 45 inches. A few gray and rust-brown mottlings are present, indicating imperfect drainage. Grass roots are in evidence, but structural units are only slightly developed. At 45 inches there is a rather abrupt transition to a dark gray material of massive structure containing somewhat more very fine sand and silt than the horizons above it. Within this horizon, which extends from 45 inches downward to the ground-water level, are strata of slightly sandier texture and lighter gray color. The darker color and slightly higher organic content indicate that the 45-inch horizon probably was once a surface soil for a long enough time to accumulate such a supply of organic matter. The slate-gray 
color indicates the deficiency of aeration and drainage, but the soil is now well penetrated by the roots of both grasses and non-grasses and the channels left by the decay of former generations of roots.

\section{Root habits of plants excavated}

The vegetation on the square meter selected for the excavation in the little bluestem prairie was about 87 per cent Andropogon scoparius. It was free from coarse-rooted forbs but supported small amounts of Antennaria campestris and Aster multiflorus. A few other grasses also occurred. These are so similar to little bluestem in root habit that the latter alone need be described. Andropogon scoparius developed a great mass of fine roots only o. I to $0.8 \mathrm{~mm}$. in diameter. The roots were so abundant that they formed a dense sod. Many of them penetrated more or less vertically or obliquely downward, some reaching a depth of 4 feet. Others spread horizontally or obliquely in the surface soil. The surface foot was especially well occupied with dense masses of finely branched roots. They were also abundant in the second and third foot and even the fourth foot of soil was fairly well interspersed with fine roots, all of which were profusely branched (fig. 6).

The square meter selected for excavation on the big bluestem prairie contained, in addition to the dominant, a small amount of Sorghastrum nutans and a sprinkling of Equisetum laevigatum. The very abundant roots of Andropogon furcatus grew both vertically and obliquely downward, thoroughly occupying the soil and forming a dense sod. The larger roots varied from 0.5 to $3 \mathrm{~mm}$. in diameter and a few reached a depth of 7 feet. The roots tapered so gradually that at 4 feet they were nearly as large as at the surface. All branched profusely even to near their tips (fig. 7). The roots of Sorghastrum nutans were similar in habit but did not penetrate so deeply.

The underground parts of Equisetum laevigatum were of special interest. They bulked large in amount, and have heretofore been undescribed. The tops originated from a much branched system of underground stems, which in the upper 2.5 feet of soil were mostly vertical or only slightly oblique. But from 2.5 to about 5.5 feet the stems grew horizontally or obliquely for long distances, giving rise 

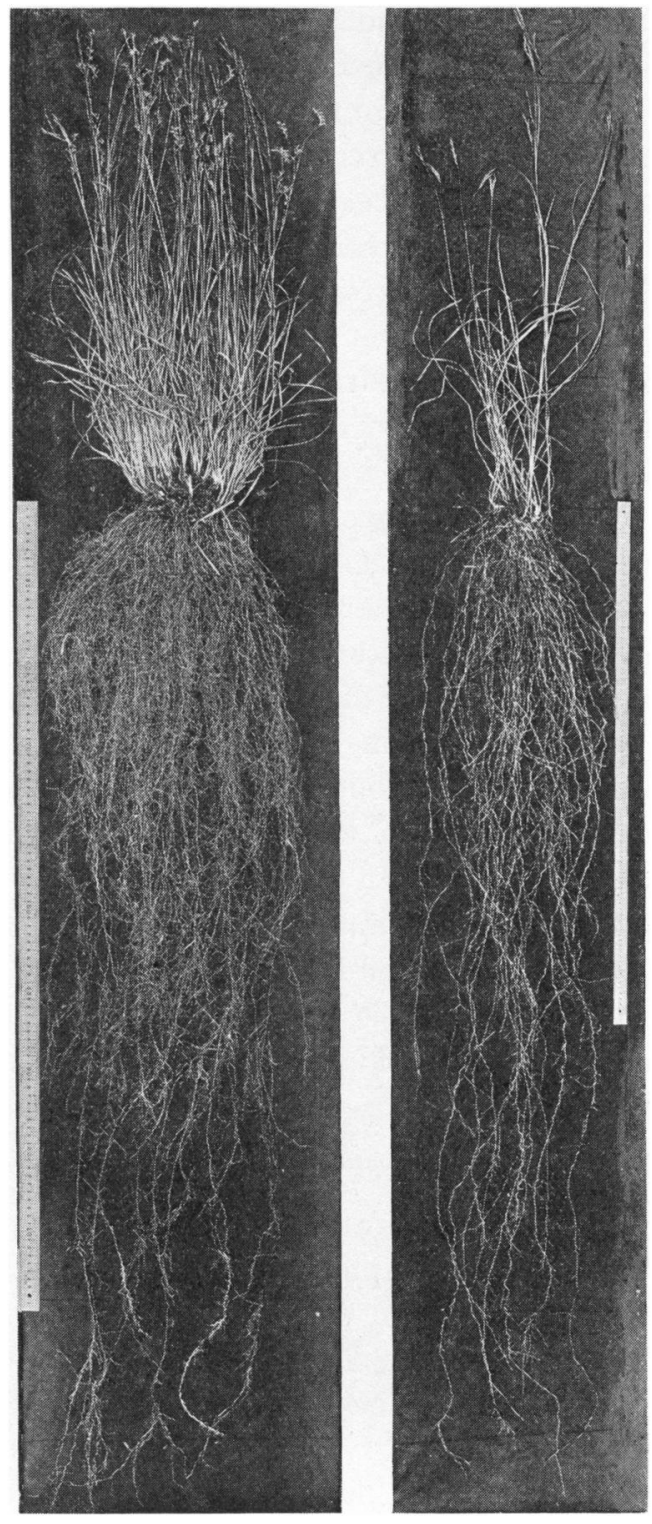

Figs. 6, 7.-Fig. 6 (left), roots and tops of mature Andropogon scoparius from high prairie; fig. 7 (right), roots and tops of mature $A$. furcatus from low prairie. Scale in both figures is a meter stick. 
to many branches which extended more or less vertically upward or downward. Some plants, however, were found that grew vertically downward to 7 feet with little or no branching. Usually the horizontal branching habit and an irregular downward course were characteristic features. Below $5 \cdot 5$ feet there were few horizontal branches, and even the vertically penetrating ones were much less abundant. The stemlike underground parts were of a steel blue or black color, distinctly jointed, and except for threadlike roots were like the parts above ground. The roots arose from the nodes or near them, often in groups of two or three but sometimes singly. A few were branched. None was found that exceeded 2.5 inches in length. In the deeper soil (usually below 5.5 feet) a type of branch arose from the horizontal stems that was apparently free from nodes, although the internal pattern, as observed with a hand lens, was similar to that of the stems. Moreover the short laterals arose irregularly all along the branch, sometimes at the rate of twelve per inch. While the underground stems were 6 to $7 \mathrm{~mm}$. in diameter these roots were often only 4 to $5 \mathrm{~mm}$. thick. Some were found that were thickly covered with a brown tomentum about $5 \mathrm{~mm}$. long resembling root hairs. Numerous roots penetrated to a depth of 7.5 feet.

All roots were separated from the soil by a process of repeated washing, after the blocks of soil had been transported to the greenhouse. It was estimated that less than I per cent of the roots was lost, a negligible amount considering the variation in root distribution in the prairie.

\section{Methods of analysis}

Soil samples for the volume-weight determinations were taken by means of special sampling equipment in use at the Nebraska Experiment Station. This equipment consists of a steel tube 4 inches in inside diameter and 2 feet long, fitted with a lining of easily removable brass cylinders, each 6 inches long. On the lower end of the steel tube is brazed a cutting ring whose inside diameter corresponds exactly with that of the brass linings. The tube is forced into the soil by means of a jack. Large augers are set in the ground about 30 inches apart, with a wooden span extending between them to serve as an anchor for the jack. A complete description of the apparatus 
will be published soon (Io). The field moisture contents and the volume-weights in table I were determined from 6-inch sections. The figures for the first and second 6-inch samples are the results of single determinations; those for all other depths are the average of the two 6-inch sections of each foot section. In each case the variation between the volume-weights of the two 6-inch sections was not more than a few hundredths.

The samples for the determination of organic matter and nitrogen and those for the determination of volume-weight were taken only a foot or two distant from the excavation made in securing the soil containing the roots. The samples for organic matter and nitrogen amounted in each case to several kilograms. They were dried and screened through a sieve of 4 meshes per inch, all roots and rhizomes being cut into pieces and mixed with the soil without loss. After thorough mixing of the large bulk sample, a I pint subsample was taken. The pint sample thus obtained was passed through a $2 \mathrm{~mm}$. sieve, all roots being ground and retained as before. No gravel larger than $2 \mathrm{~mm}$. in diameter was found in any of the samples, except an insignificant amount (less than 0.2 per cent) in the 2- to 4-foot depths of the Lancaster profile; these larger particles were discarded. The pint sample was again subsampled, about roo gm. being taken and ground to pass through a I $\mathrm{mm}$. sieve. This was used for the moisture equivalent and hygroscopic moisture determinations. Another Ioo gm. portion was ground to pass through a $0.25 \mathrm{~mm}$. sieve for the determinations of organic matter, nitrogen, and specific gravity.

The root materials were ground in a Wiley mill with a $2 \mathrm{~mm}$. sieve. The organic matter of the roots was determined by ignition in an electric furnace. Nitrogen in the roots and soils was determined by the usual Gunning method (3). Organic matter in the soils was determined by a modification of the hydrogen peroxide method of Robinson (9). Duplicate determinations agreed within a few hundredths of I per cent. RUSSEL and ENGLE (I2) have shown that the method is reliable and yields results agreeing closely with those obtained by multiplying organic carbon content by the conventional factor 1.724 .

The hygroscopic coefficient was determined by the method of 
Alway, Kline, and McDole (r). The moisture equivalent was determined as described by RUSSEL and BURR (II). The specific gravity determinations were made by means of the pycnometer. The samples of both soils and roots for moisture determination were dried at $110^{\circ} \mathrm{C}$; t the organic matter, nitrogen, and moisture percentages were calculated on the basis of oven-dry sample weights.

\section{Results}

The moisture and volume relations of the soils are shown in table I. Mechanical analyses were not made, since the soil texture is clearly indicated by the hygroscopic coefficients.

TABLE I

MOISTURE AND VOLUME RELATIONS IN THE SOILS

\begin{tabular}{|c|c|c|c|c|c|c|c|c|}
\hline $\begin{array}{l}\text { DEPTH } \\
\text { (FEET OR } \\
\text { INCHES) }\end{array}$ & $\begin{array}{c}\text { HYGRO- } \\
\text { SCOPIC } \\
\text { COEFFI- } \\
\text { CIENT }(\%)\end{array}$ & $\begin{array}{c}\text { FIELD } \\
\text { MOISTURE } \\
\text { CONTENT } \\
\text { (F.M.C.) } \\
(\%)\end{array}$ & $\begin{array}{c}\text { MoISTURE } \\
\text { EQUIVA- } \\
\text { LENT }(\%)\end{array}$ & $\begin{array}{l}\text { Volume- } \\
\text { WEIGHT } \\
\text { (GM./CC.) }\end{array}$ & $\begin{array}{l}\text { SPECIFIC } \\
\text { GRAVITY }\end{array}$ & $\begin{array}{c}\text { PORE } \\
\text { SPACE } \\
(\%)\end{array}$ & $\begin{array}{c}\text { SPACE } \\
\text { OCCUPIED } \\
\text { BY WATER } \\
\text { AT } \\
\text { F.M.C. } \\
(\%)\end{array}$ & $\begin{array}{c}\text { AIR SPACE } \\
\text { AT F.M.C. } \\
(\%)\end{array}$ \\
\hline & \multicolumn{8}{|c|}{ Lancaster loam at Belmont prairie } \\
\hline $\begin{array}{l}0-6^{\prime \prime} \\
6-12^{\prime \prime} \\
\mathrm{I}-2^{\prime} \\
2-3^{\prime} \\
3-4^{\prime}\end{array}$ & $\begin{array}{r}\text { II } .0 \\
\text { I } 2.8 \\
\text { I } 2.6 \\
9.6 \\
5.6\end{array}$ & $\begin{array}{l}30.4 \\
21.9 \\
\text { r } 4.9 \\
\text { r } 5.7 \\
\text { r } 3.5\end{array}$ & $\begin{array}{l}35.4 \\
41.0 \\
37.8 \\
28.7 \\
14.8\end{array}$ & $\begin{array}{l}\text { I. I } 2 \\
I .3 I \\
\text { I. } 4 \text { I } \\
\text { I. } 55 \\
\text { I. } 64\end{array}$ & $\begin{array}{l}2.59 \\
2.62 \\
2.63 \\
2.70 \\
2.68\end{array}$ & $\begin{array}{l}56.8 \\
50.0 \\
46.4 \\
42.6 \\
38.8\end{array}$ & $\begin{array}{l}34 \cdot I \\
28.7 \\
21.0 \\
24 \cdot 3 \\
22 . I\end{array}$ & $\begin{array}{l}22.7 \\
2 \mathrm{I} \cdot 3 \\
25 \cdot 4 \\
\mathrm{I} 8.3 \\
\mathrm{I} 6.7\end{array}$ \\
\hline \multicolumn{9}{|c|}{ Wabash clay loam at Everett prairie } \\
\hline $\begin{array}{l}o-6^{\prime \prime} \\
6-\mathrm{r} 2^{\prime \prime} \\
1-2^{\prime} \\
2-3^{\prime} \\
3-4^{\prime} \\
4-5^{\prime} \\
5-6^{\prime} \\
6-7^{\prime}\end{array}$ & $\begin{array}{l}\text { I8.2 } \\
\text { I9.7 } \\
\text { I5.6 } \\
\text { I } 4.6 \\
\text { I5.8 } \\
\text { I5.6 } \\
\text { I } 4.2 \\
\text { I2.8 }\end{array}$ & $\begin{array}{l}20.7 \\
24.2 \\
23.2 \\
25.8 \\
29.2 \\
32.6 \\
31.4 \\
30.8\end{array}$ & $\begin{array}{l}41 \cdot 9 \\
43 \cdot 4 \\
36.1 \\
34.1 \\
36.1 \\
36.2 \\
35 \cdot 5 \\
34 \cdot 0\end{array}$ & $\begin{array}{l}\text { I.05 } \\
\text { I. I6 } \\
\text { I. IO } \\
\text { I. I9 } \\
\text { I. } 20 \\
\text { I. } 27 \\
\text { I. } 24 \\
\text { I. } 33\end{array}$ & $\begin{array}{l}2.60 \\
2.68 \\
2.6 \mathrm{I} \\
2.66 \\
2.66 \\
2.65 \\
2.66 \\
2.69\end{array}$ & $\begin{array}{l}59.6 \\
56.7 \\
57.9 \\
55.3 \\
54.9 \\
52.1 \\
53.4 \\
50.6\end{array}$ & $\begin{array}{l}2 I \cdot 7 \\
28 . I \\
25 \cdot 5 \\
30.7 \\
35.0 \\
41.4 \\
38.9 \\
41.0\end{array}$ & $\begin{array}{r}37.9 \\
28.6 \\
32.4 \\
24.6 \\
19.9 \\
10.7 \\
14.5 \\
9.6\end{array}$ \\
\hline
\end{tabular}

TEXTURE.-The figure II.o for the surface 6 inches of the Lancaster loam indicates a rather heavy loam texture; the greater hygroscopic coefficients of the 6- to 24 -inch layer and the decreasing 
figures below this depth agree well with the field observation of a clay horizon in the second foot and an increasing sandiness below this horizon.

In the Wabash clay loam the variations in hygroscopic coefficients may be taken to indicate corresponding variations in texture, the second 6 inches being the most clayey and the seventh foot the least clayey in the profile. Since this is an alluvial soil, no consistent variations can be found in the hygroscopic coefficients as the result of weathering processes in the profile, the texture of the deposited material having overshadowed any possible effects of weathering.

MoISTURE Equivalent.-The moisture equivalents of the Lancaster soil samples are approximately three times the hygroscopic coefficients; those of the Wabash soils are approximately 2.5 times the hygroscopic coefficients. The moisture equivalent gives an approximate indication of the field moisture carrying capacity of the soil but exceeds it appreciably in soils of heavy texture. For example, the field moisture contents of the surface 6 inches of Lancaster loam, and of the lower 4 feet of the Wabash clay loam, were probably close to the field carrying capacity at the time of sampling, but they were appreciably lower than the moisture equivalents. Both soils had been dried considerably by the grass roots, as is indicated by their field moisture contents at the time of sampling, which are shown in table I.

Volume-Weight.-The volume-weight of a soil is the weight of dry soil per unit volume. It is expressed in table I as grams per cubic centimeter. The volume-weight of the surface 6 inches of the Lancaster loam (I.I 2 ) may be considered a typical figure for virgin prairie soils of medium texture. It is low in comparison with that of the deeper horizons because of the high degree of granulation and the presence of a large amount of root material in the surface soil. The increasing volume-weight with increasing depth is correlated with decreasing granulation and also with increasing sandiness of texture. The figures I. 55 and I.64 for the third and fourth foot sections indicate a high degree of compactness.

The volume-weight of the surface section of the Wabash soil is exceptionally low, owing to the highly granular structure of this horizon and the presence of a large volume of roots and rhizomes. The 
volume-weight of the second foot is noticeably lower than that of the second 6 inches; it corresponds to that of a surface soil. This fact is in harmony with the field observation that the second-foot section is a buried surface soil. Below this level the volume-weight increased consistently with greater depth and less intensive root penetration and weathering.

SpeCIFIC GRAVITY.-The specific gravity of the soil is influenced to some extent by the organic content. This fact is well illustrated by the figures given in table I. In the Lancaster loam the specific gravity increased with depth as the organic matter decreased. In the Wabash clay loam the specific gravity of the second-foot section was lower than that of the horizons above or below, corresponding with the higher organic content of this section. Below the 3 -foot level the variations in specific gravity in this profile were of no significance.

PORE SPACE.-The pore space of the soil was calculated from the formula

$$
\mathrm{P}=100-\left(\frac{100 \mathrm{~V}}{\mathrm{~S}}\right),
$$

in which $\mathrm{P}=$ per cent pore space, $\mathrm{V}=$ volume-weight, and $\mathrm{S}=$ specific gravity. The pore space decreases with depth as a general rule, being mainly an inverse function of the volume-weight. This relation is more obvious in the case of the Lancaster loam because of the sandier texture of the deeper horizons. Sandy soils as a rule have greater volume-weight and less pore space than heavy soils.

The percentage of the total soil volume occupied by water at any water content is readily calculated by multiplying the percentage of water on the dry weight basis by the volume-weight. This method has been used to calculate the percentage of the total volume of soil occupied by water at the field moisture content at the time of sampling. The difference between the total pore space and the space occupied by water is the percentage of air space in the soil at the water content in question. In figures 8 and 9 the air space is based upon the average water content of the soil during the season of 1932 .

The data on air space at field moisture content in the Lancaster 
loam indicate a well aerated profile throughout. The decrease in air space at the lower depths is due to the sandier texture and consequent smaller total pore space, while the decrease in air space in the deeper horizons of the Wabash soil is the result of higher water content. Even in the seventh foot, however, which was just above the ground-water level, the pore space of the soil was not entirely filled

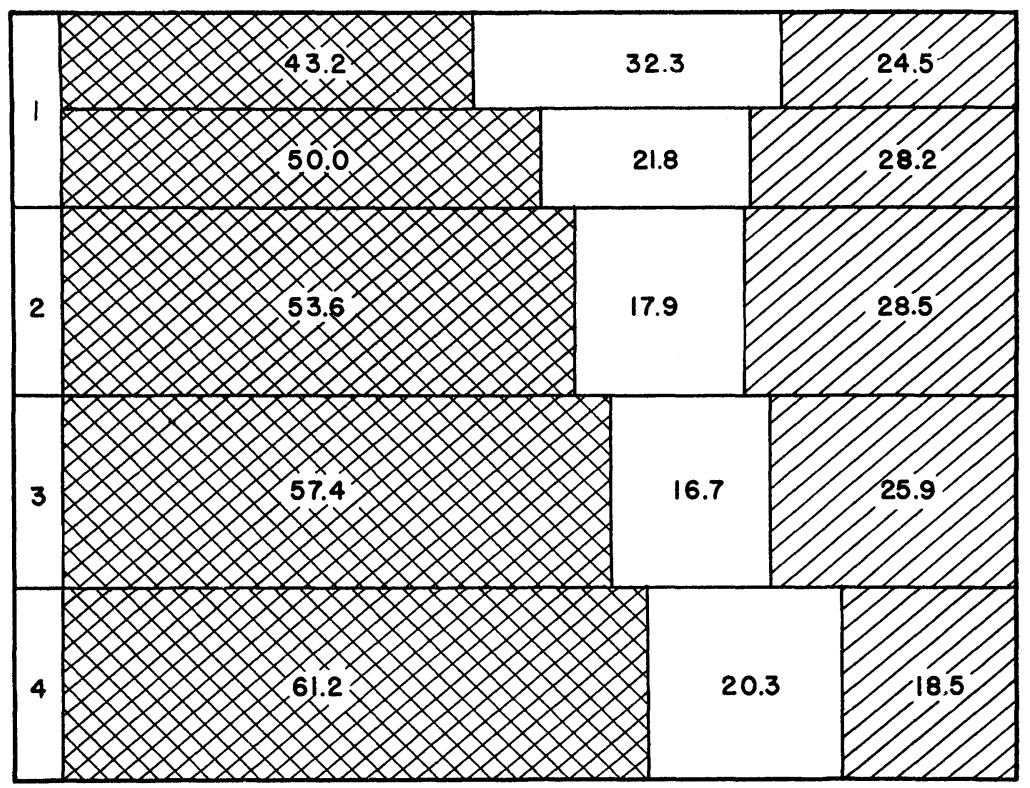

FIG. 8.-Diagram showing percentage of solid matter (cross hatch) and total pore space in first 4 feet of Lancaster loam soil covered with Andropogon scoparius. Portion of pore space occupied by water (single hatch) is based upon average water content during $193^{2}$; unhatched part is air space.

with water; about Io per cent of the soil volume, or one-fifth of the total pore space, was occupied by air.

ORGANIC MATTER AND NITROGEN OF SOILS.-In table II are presented the soil organic matter and nitrogen relations in the two profiles. The nitrogen in the soil organic matter (fifth column) is the reciprocal of the ratio of organic matter to nitrogen (fourth column) and is added for the convenience of those who are accustomed to think of the relation between nitrogen and organic matter on a percentage basis rather than as a ratio. The carbon-nitrogen 
ratio (sixth column) has been calculated from the organic matternitrogen ratio by dividing by the conventional factor 1.724 . It is

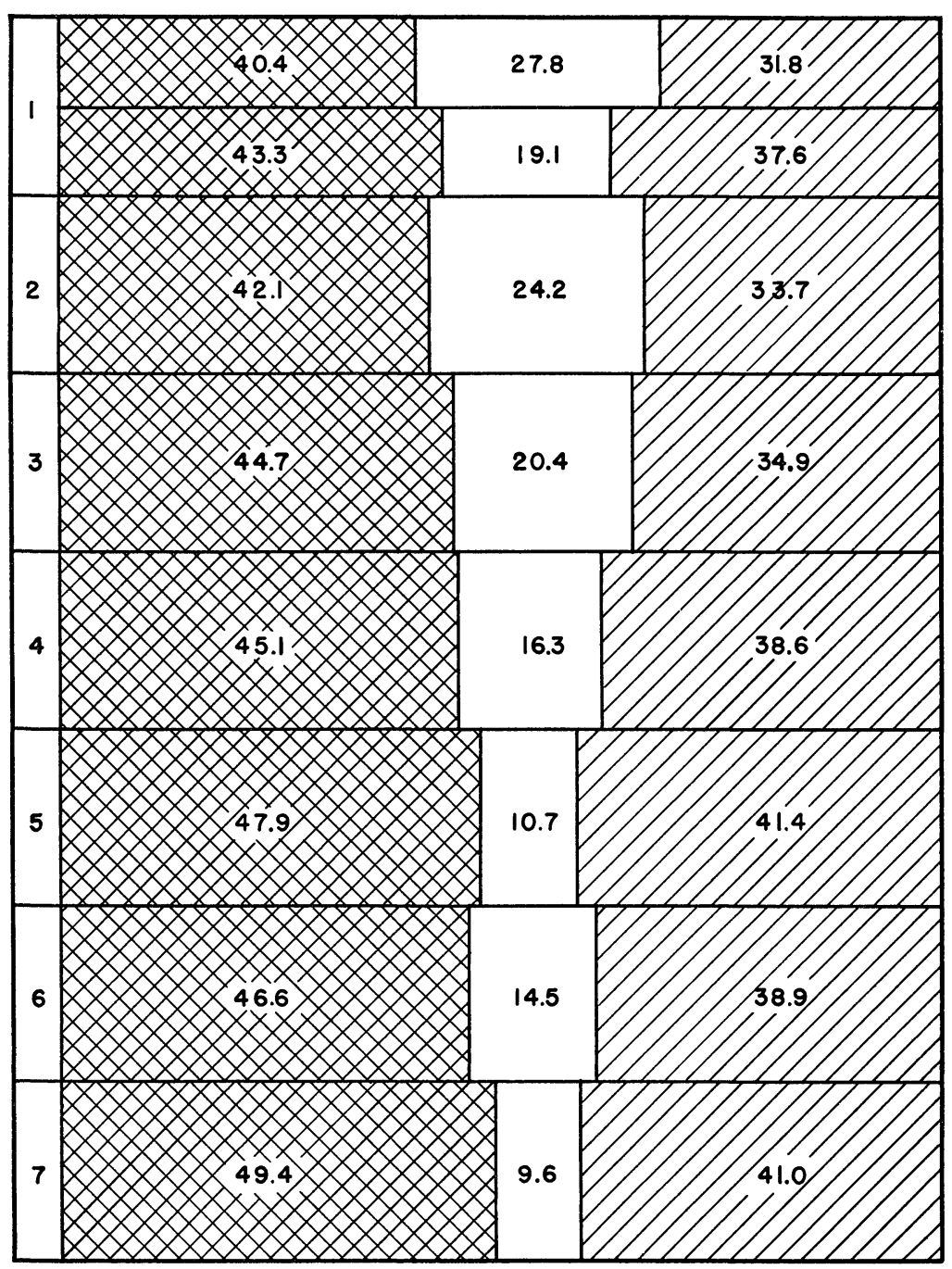

FIG. 9.-Diagram showing percentage of solid matter, air space, and water in the first 7 feet of Wabash clay loam soil covered with Andropogon furcatus. Legend and conditions as in figure 8.

presented for the purpose of comparison with other carbon-nitrogen ratios in the literature. 
The weight of soil per square meter (seventh column) has been calculated from the volume-weight. The first two figures for each soil are for 6-inch sections, while the other figures correspond to I-foot sections. Since the volume of one square meter to the depth of 6 inches is $152,400 \mathrm{cc}$., the weight of soil in grams per square meter for the 6-inch sections is obtained by multiplying this figure by the volume-weight; for the foot sections, weight per square meter equals

TABLE II

ORGANIC MATTER AND NITROGEN RELATIONS IN THE SOILS

\begin{tabular}{|c|c|c|c|c|c|c|c|c|}
\hline $\begin{array}{l}\text { DEPTH } \\
\text { (FEET OR } \\
\text { INCHES) }\end{array}$ & $\begin{array}{c}\text { ORGANIC } \\
\text { MATTER } \\
(\%)\end{array}$ & $\begin{array}{c}\text { Nitrogen } \\
(\%)\end{array}$ & $\begin{array}{l}\text { Ratio } \\
\mathrm{OM} / \mathrm{N}\end{array}$ & $\begin{array}{l}\text { Nitrogen } \\
\text { IN SoIL } \\
\text { OM }(\%)\end{array}$ & $\begin{array}{c}\text { Ratio } \\
\mathrm{C} / \mathrm{N}\end{array}$ & $\begin{array}{c}\text { WT. OF } \\
\text { SOIL PER } \\
\text { SQ.M. } \\
\text { IN KG. }\end{array}$ & $\begin{array}{c}\text { ORGANIC } \\
\text { MATTER } \\
\text { (GM./SQ. } \\
\text { M.) }\end{array}$ & $\begin{array}{l}\text { Nitrogen } \\
\text { (GM./sQ. } \\
\text { M.) }\end{array}$ \\
\hline & \multicolumn{8}{|c|}{ Lancaster loam at Belmont prairie } \\
\hline $\begin{array}{l}\text { O-6 } 6^{\prime \prime} \\
6-\mathrm{I} 2^{\prime \prime} \\
\mathrm{I}-2^{\prime} \\
2-3^{\prime} \\
3-4^{\prime}\end{array}$ & $\begin{array}{l}4.50 \\
3.24 \\
1.59 \\
0.43 \\
0.20\end{array}$ & $\begin{array}{r}0.224 \\
.167 \\
.093 \\
.043 \\
.024\end{array}$ & $\begin{array}{r}20.0 \\
\text { I } 9.4 \\
\text { I } 7.1 \\
\text { I0.0 } \\
8.3\end{array}$ & $\begin{array}{r}5.0 \\
5.2 \\
5.8 \\
10.0 \\
\text { I } 2.0\end{array}$ & $\begin{array}{r}\text { I I . } 6 \\
\text { I I .3 } \\
9.9 \\
5.8 \\
4.8\end{array}$ & $\begin{array}{l}\text { I } 71 \\
200 \\
430 \\
472 \\
500\end{array}$ & $\begin{array}{l}7670 \\
6480 \\
6840 \\
2030 \\
1000\end{array}$ & $\begin{array}{l}382 \\
334 \\
400 \\
203 \\
\mathrm{I} 20\end{array}$ \\
\hline & \multicolumn{8}{|c|}{ Wabash clay loam at Everett prairie } \\
\hline $\begin{array}{l}\text { O-6 } 6^{\prime \prime} \\
6-\mathrm{I} 2^{\prime \prime} \\
\mathrm{I}-2^{\prime} \\
2-3^{\prime} \\
3-4^{\prime} \\
4-5^{\prime} \\
5-6^{\prime} \\
6-7^{\prime}\end{array}$ & $\begin{array}{l}4.92 \\
2.24 \\
2.77 \\
\text { I. } 75 \\
\text { I. } 24 \\
\text { I. } 44 \\
\text { I. } 22 \\
\text { I.02 }\end{array}$ & $\begin{array}{r}.262 \\
.138 \\
.167 \\
.114 \\
.088 \\
.078 \\
.074 \\
0.061\end{array}$ & $\begin{array}{l}\text { I8.8 } \\
\text { I6.2 } \\
\text { I6.6 } \\
\text { I5 } 5.3 \\
\text { I4. I } \\
\text { I8 } 6.5 \\
\text { I6.5 } \\
\text { I6.7 }\end{array}$ & $\begin{array}{l}5.3 \\
6.2 \\
6.0 \\
6.5 \\
7.1 \\
5.4 \\
6.1 \\
6.0\end{array}$ & $\begin{array}{r}\text { I0.9 } \\
9.4 \\
9.6 \\
8.9 \\
8.2 \\
\text { 10.7 } \\
9.6 \\
9.7\end{array}$ & $\begin{array}{l}\text { I } 60 \\
\text { I } 77 \\
335 \\
363 \\
366 \\
387 \\
378 \\
405\end{array}$ & $\begin{array}{l}7880 \\
3960 \\
9280 \\
6340 \\
4540 \\
5580 \\
4600 \\
4140\end{array}$ & $\begin{array}{l}420 \\
244 \\
560 \\
414 \\
322 \\
302 \\
280 \\
248\end{array}$ \\
\hline
\end{tabular}

volume-weight $X_{152,400} X_{2}$. The weights given in the table are expressed in kilograms. These figures were used in converting the percentage of organic matter and nitrogen in the soil to grams per square meter in order to obtain the weight of soil organic matter and nitrogen in the volume of soil from which the roots were taken, as shown in the last two columns of table II.

The organic matter and nitrogen data for the Lancaster loam show the profile characteristics usually found in normal grassland soils. According to the extensive work of Alway and McDole (2) and of 
Russel and McRuer (13) in grassland soils, the nitrogen and organic matter decrease regularly with depth, the bulk of the organic matter being confined to the surface foot. In the first and second 6-inch sections, the organic matter and nitrogen contents are in agreement with those found by these investigators for soils of this texture in this part of the state; in the lower sections the organic content decreases more rapidly as a result of their sandy texture. The organic matter-nitrogen ratios throughout the profile are typical of the upland soils of this region.

The percentage of organic matter and nitrogen in the second foot of the Wabash silt loam is considerably higher than that in the 6-inch section just above it, correlating perfectly with the field observation that this layer shows the characteristics of a well developed surface soil. In virgin prairie soils, a higher nitrogen content is never found in a lower layer than in layers above, except in cases of buried soil profiles or where silting by wind or water has occurred comparatively recently (13). The ratio of organic matter to nitrogen shows a tendency toward that of the surface soil, for although the ratio i 6.6 is perhaps not significantly higher than the ratio $\mathrm{I} 6.2$ in the second 6 inches, yet if the profile showed the characteristics of a mature soil, the ratio in the second foot should be significantly lower than I6.2. This is illustrated by the organic matter-nitrogen ratios of the Lancaster loam.

The relatively high values for the organic matter-nitrogen ratios of the lower 3 feet of the profile are believed to indicate that the 4foot level also was at one time a surface soil. The slightly higher organic content of the fifth foot in comparison with the fourth foot is in agreement with this conclusion. In the field a rather abrupt change in the appearance and properties of the soil was observed at approximately the 4 -foot level.

It seems remarkable that the soil organic matter should retain its characteristics after being buried and subjected to decomposition and weathering for a period that was undoubtedly several hundred years in duration, but the data in table II indicate that such is the case.

DRY Weight, ORGanic MatTER, AND NITROgen OF ROOTS.-The dry weight, organic matter, and nitrogen of the roots recovered from 
each section of the Lancaster loam are shown in table III. Nearly 60 per cent of the total root system was found in the upper 6 inches of soil. This, however, includes the rhizomes.

The high organic matter of the roots and short rhizomes of the little bluestem in the surface foot of soil is probably due to the presence of stored food reserves. The lower figures in the second and third foot may be due to decortication of the older roots in these sections, while the increase in the fourth foot may result from this portion of the root system containing the younger and smaller rootends which often have a relatively larger proportion of living tissues.

TABLE III

DRY WEIGHT, ORGANIC MATTER, AND NITROGEN IN ROOTS FROM ONE SQUARE METER OF LANCASTER LOAM

\begin{tabular}{|c|c|c|c|c|c|}
\hline $\begin{array}{l}\text { DEPTH (FEET } \\
\text { OR INCHES) }\end{array}$ & $\begin{array}{l}\text { DRY WEIGHT } \\
\text { (GM.) }\end{array}$ & $\begin{array}{c}\text { Organic } \\
\text { Matter }(\%)\end{array}$ & $\begin{array}{l}\text { Nitrogen } \\
(\%)\end{array}$ & $\begin{array}{c}\text { ORGANIC } \\
\text { MATTER (GM.) }\end{array}$ & $\begin{array}{l}\text { Nitrogen } \\
\text { (GM.) }\end{array}$ \\
\hline o- $6^{\prime \prime}$ & $741.0^{*}$ & 90.8 & 0.828 & 657 & 6.13 \\
\hline $6-12^{\prime \prime}$ & I98.0 & 9 I. 7 & 0.699 & 182 & I. 39 \\
\hline$I-2^{\prime}$ & 193.0 & $83 . I$ & 0.656 & 160 & I. 26 \\
\hline $2-3^{\prime}$ & 85.5 & 86.6 & 0.730 & 74 & 0.62 \\
\hline $3-4^{\prime}$ & 12.0 & 9 I. 4 & 0.800 & $\begin{array}{l}14 \\
\text { I I }\end{array}$ & 0.10 \\
\hline
\end{tabular}

* This includes also the rhizomes of the grasses all of which occurred in the surface 6 inches of soil.

In the Wabash profile it was possible to separate the grass roots from the non-grasses and in the surface layer to separate the grass roots from the rhizomes. The dry weight, organic matter, and nitrogen in these roots and rhizomes are shown in table IV. In the fifth foot and deeper, the quantity of grass roots alone was too small for analysis, hence the grasses and non-grasses were mixed. The organic matter in the non-grasses above the fifth foot varied from 78 to 88 per cent, with no consistent relation to depth. The high organic matter and nitrogen content of the rhizomes, 94 and 0.73 per cent respectively, may be attributed to their store of food reserves. The organic matter of the grass roots in the surface 6 inches, 74 per cent, was found to be considerably lower than in the deeper horizons, where the figure varied from $8 \mathrm{I}$ to $9 \mathrm{I}$ per cent. This may be due to the high degree of decortication of the older roots in the surface layer and to the leaching of soluble organic matter from the dead and 
partly decayed roots. Unfortunately the roots and rhizomes of the little bluestem in the Lancaster soil were not separated, and the

TABLE IV

DRY WEIGHT, ORGANIC MATTER, AND NITROGEN IN ROOTS FROM ONE SQUARE METER OF WABASH CLAY LOAM

\begin{tabular}{|c|c|c|c|c|c|c|}
\hline $\begin{array}{l}\text { DEPTH } \\
\text { (FEET OR } \\
\text { INCHES) }\end{array}$ & KIND OF ROOTS, ETC. & $\begin{array}{c}\text { DRY } \\
\text { WEIGHT } \\
\text { (GM.) }\end{array}$ & $\begin{array}{c}\text { ORGANIC } \\
\text { MATTER } \\
(\%)\end{array}$ & $\begin{array}{l}\text { Nitrogen } \\
(\%)\end{array}$ & $\begin{array}{c}\text { ORGANIC } \\
\text { MATTER } \\
\text { (GM.) }\end{array}$ & $\begin{array}{l}\text { Nitrogen } \\
\text { (GM.) }\end{array}$ \\
\hline \multirow[t]{4}{*}{ o-6" } & Non-grasses* & 23.2 & $84 \cdot 3$ & 0.594 & I9. 6 & o. 138 \\
\hline & Grasses & 726 & $74 \cdot 3$ & $.5 \mathrm{I} 5$ & 539 & $3 \cdot 74$ \\
\hline & Rhizomes of grasses & 292 & 94.0 & .728 & 274 & 2. I 2 \\
\hline & Total. . & IO4 I & & & 833 & $6 . \infty 0$ \\
\hline \multirow[t]{3}{*}{$6-\mathrm{I} 2^{\prime \prime}$} & Non-grasses & $\mathrm{I} 2.4$ & 86.0 & .372 & I0. 6 & .046 \\
\hline & Grasses & I68 & 84.6 & .500 & 142 & .838 \\
\hline & Total. & I 80 & & $\ldots$ & I 53 & .884 \\
\hline \multirow[t]{3}{*}{$I-2^{\prime}$} & Non-grasses & 34.0 & $78 \cdot 3$ & .340 & 26.6 & O. II 6 \\
\hline & Grasses & I 79 & $8 \mathrm{I} .0$ & .532 & I 45 & .954 \\
\hline & Total. . & $2 \mathrm{I} 3$ & & $\ldots \ldots$ & 172 & I. .07 \\
\hline \multirow[t]{3}{*}{$2-3^{\prime}$} & Non-grasses & 43.6 & 86.3 & .301 & 37.6 & .132 \\
\hline & Grasses & 80.2 & 87.8 & .514 & 70.8 & $.4 \mathrm{I} 2$ \\
\hline & Total. & I 24 & & & 108 & 0.544 \\
\hline \multirow[t]{3}{*}{$3-4^{\prime}$} & Non-grasses & 22.0 & 88.0 & .305 & 19.4 & .066 \\
\hline & Grasses & 42.2 & 90.8 & $.45^{6}$ & 38.2 &. $\mathrm{I} 94$ \\
\hline & Total. & 64.2 & & & 57.6 & .260 \\
\hline \multirow[t]{3}{*}{$4-5^{\prime}$} & Non-grasses & 42.6 & & & & \\
\hline & Grasses & I 4.0 & & & & $\cdots \cdots$ \\
\hline & Total. . & 56.6 & 87.4 & 0.332 & $49 \cdot 4$ & . 188 \\
\hline \multirow[t]{2}{*}{$5^{-6^{\prime}}$} & $\begin{array}{l}\text { Non-grasses } \\
\text { Grasses }\end{array}$ & $\begin{array}{r}\text { II } .4 \\
2.6\end{array}$ & & & & \\
\hline & Total. & I 4.0 & 90.2 & .342 & I 2.6 & 0.048 \\
\hline \multirow[t]{3}{*}{$6-7^{\prime}$} & Non-grasses & II .4 & $\cdots$ & $\cdots$ & . & ....... \\
\hline & Giasses & . & & & & $\cdots$ \\
\hline & Total. . & I 2.0 & $78 . \mathrm{I}$ & 0.409 & $9 \cdot 4$ & 0.049 \\
\hline
\end{tabular}

* Non-grasses are very largely Equisetum laevigatum.

separate composition of each of these structures alone is not known. The data in table $\mathrm{V}$ are taken from the preceding tables. They 
permit several conclusions to be drawn concerning the relationships between the depth in the soil profile, the quantity of organic matter present, the quantity of roots, and the type of decomposition of the dead root material. It should be borne in mind that the "soil organic matter" of the tables includes that of the root material. This is the case because in the routine preparation of soil samples for analysis it is not practicable to remove all of the root material from the soil,

TABLE V

ORGANIC MATTER AND NITROGEN RELATIONS BETWEEN SOILS AND ROOTS

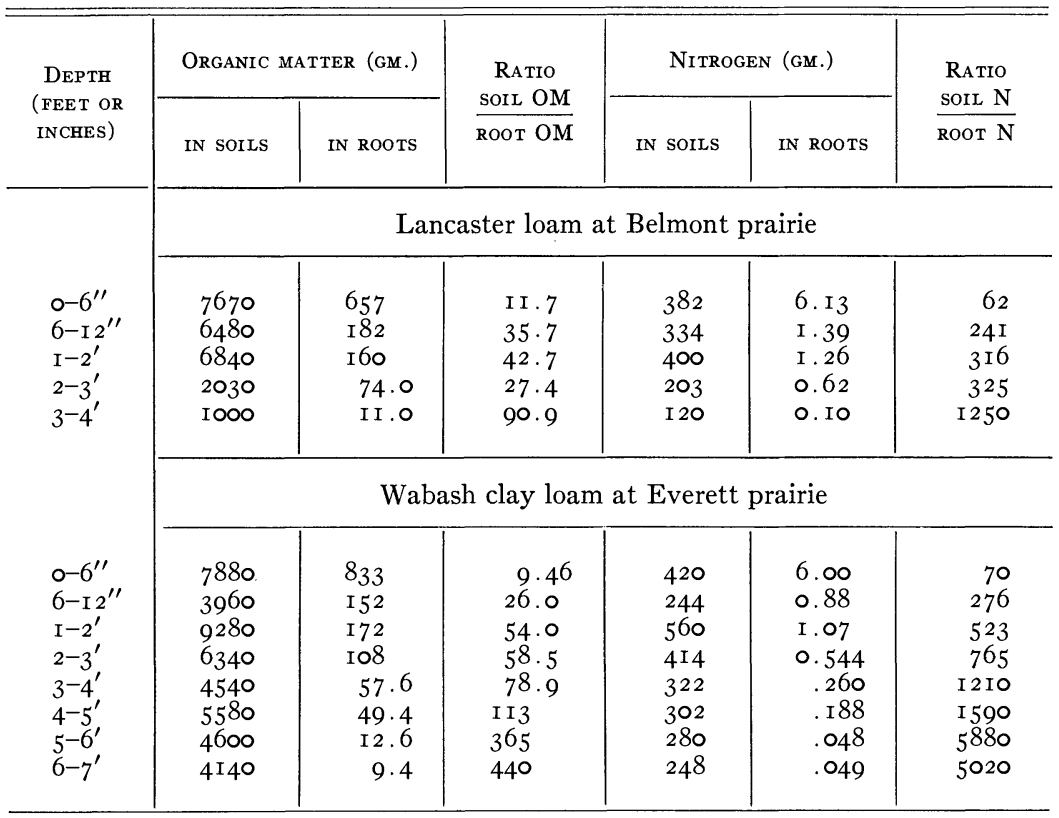

nor is it possible to remove a part of this material without introducing the factor of personal judgment as to how much of the coarse roots should be sifted out and how much should be retained. The only simple method of avoiding the personal factor is to retain all of the root material, and this is the usual procedure in obtaining and preparing soil samples for analysis.

In the surface soil, according to table $\mathrm{V}$, approximately one-tenth of the "soil organic matter" consists of plant roots and rhizomes, so that whether or not they are included as a part of the soil sample is a 
matter of some importance. In the deeper layers the roots are of relatively less importance as a part of the organic matter of the soil. Figure ro shows graphically the relations between the depth in the soil and the ratio of soil organic matter to the organic matter of the roots throughout each of the two profiles, and illustrates the fact that with increasing depth the mass of the roots becomes decreasingly important in proportion to that of the soil organic matter. The ratio of soil organic matter to the organic matter of the roots is roughly a linear function of the depth in the Lancaster profile. This is also true in the Wabash profile to the depth of 5 feet, but in the sixth and seventh foot the quantity of soil organic matter is far out of proportion to the quantity of roots. This is probably due to the excessive water content and deficient aeration which tend to inhibit the complete decomposition of organic matter and preserve it in the soil in the partly decomposed or humified state. The same statements apply to the relation between the depth in the profile and the ratio of soil nitrogen to root nitrogen which is not shown graphically because of its similarity to the organic matter relation.

The point corresponding to the 3 -foot depth in the Lancaster soil deviates widely from the other points in this profile with respect to both organic matter and nitrogen ratios. This is believed to be due to the fact that the third foot is a sandy horizon, very permeable to grass roots, and capable of holding sufficient water and air for the rapid decomposition of dead roots. These conditions might be expected to result in the presence of a relatively large mass of living roots and a small amount of dead residues.

The quantity of roots found at any level in the soil depends to some extent on the fertility and physical properties of the soil, but is principally dependent upon the nature of the plant, unless the soil departs widely in parts of the profile from the conditions of texture, structure, fertility, and moisture usually found in the grassland soils of this region. In the case of the Wabash soil, it is evident that the organic matter of the soil has had no great influence on root development, for the 6- to I 2-inch level contained 2.24 per cent of organic matter and o. Io per cent of root material, while the I- to 2 -foot section contained 2.77 per cent of organic matter and only 0.06 per cent of root material. The lower layer of soil, relatively one-fifth 


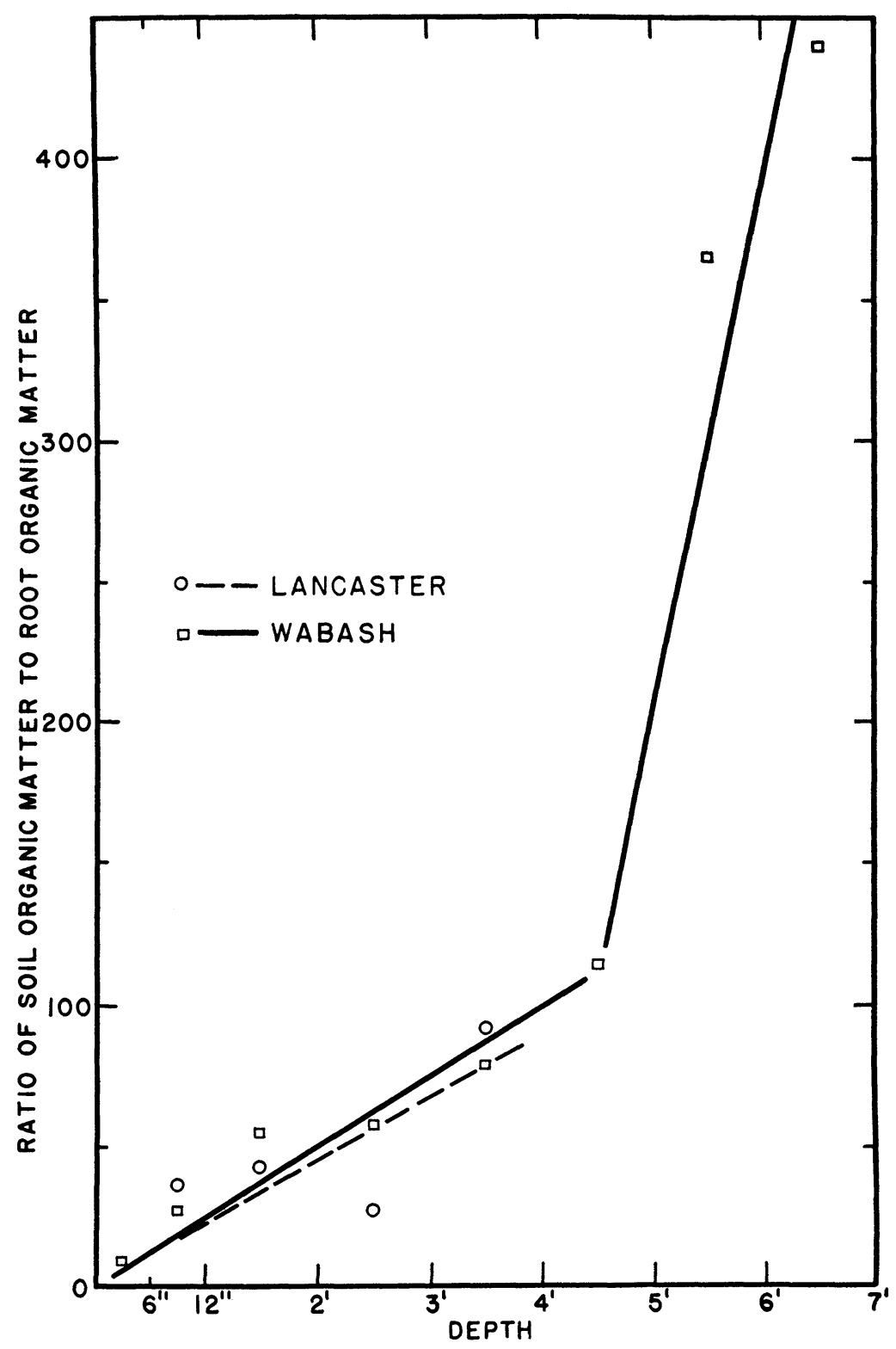

FIG. I0.- Relation between depth in profile and ratio of soil organic matter to root organic matter. 
richer in total organic matter, was relatively two-fifths poorer in root material.

The relation between the amount of organic matter in the soil and that in the roots is shown graphically in figure I $\mathrm{I}$. The data for the organic matter of both soil and roots in the first and second 6-inch sections have been multiplied by two in order to place all the data on

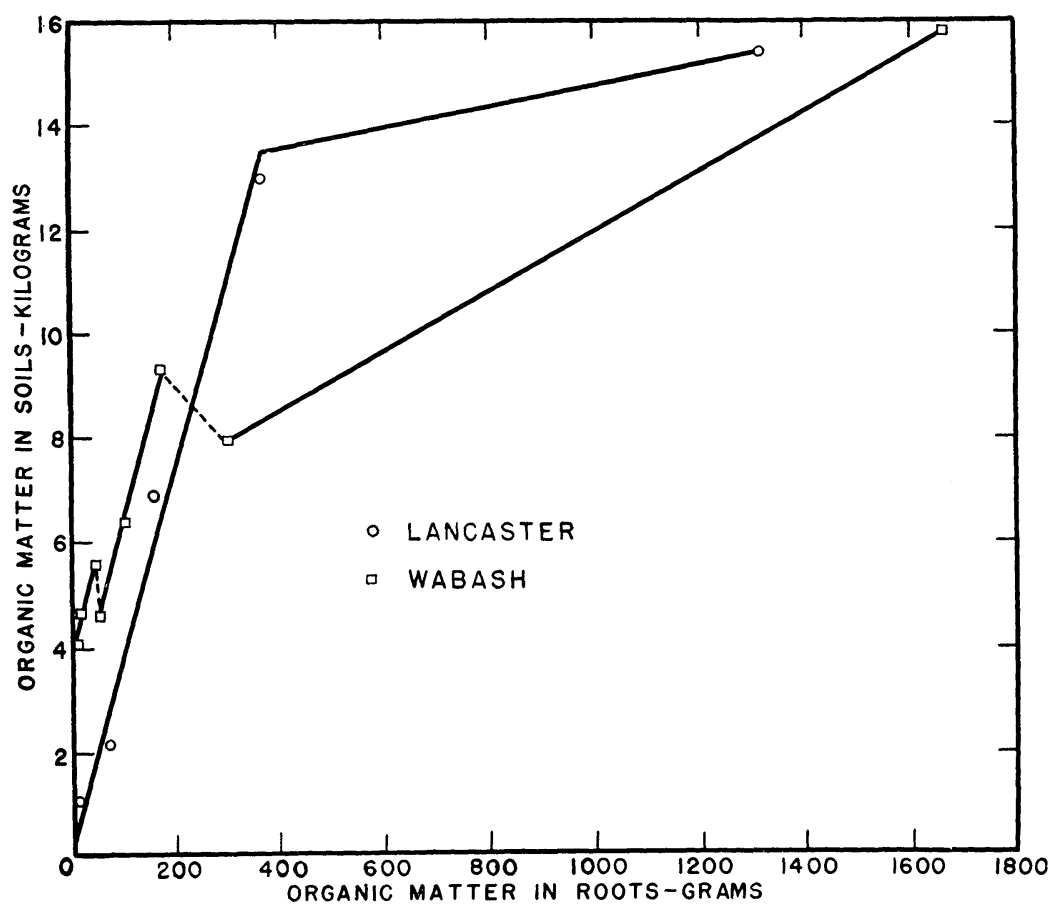

FIG. II.-Relation of organic matter in roots to organic matter in soils.

the foot-section basis. The graph for the Lancaster soil is approximately a straight-line function except in the surface 6 inches, where the large mass of roots far exceeds the proportionate amount of soil organic matter. In the Wabash soil, however, there are breaks in the curve, corresponding to the positions of the buried surface soils in the profile. Between these points of discontinuity the slope of the curve is approximately the same as for the Lancaster soil. Although it is not advisable to make a positive statement based on the study 
of but two profiles, these results suggest a possible constant relation, except in the surface layer of soil, between root development and soil organic matter.

\section{Discussion}

The nitrogen content of the soil organic matter is dependent on the climatic and soil conditions, and the character and amount of plant growth. Under virgin conditions the plant growth ultimately reaches an equilibrium which is the result of the interaction of the climatic conditions, the soil conditions, and the plant growth itself. The nitrogen content of the soil organic matter, which may also be expressed in the form of the carbon-nitrogen ratio or the organic matter-nitrogen ratio, is thus the result of an equilibrium between the accumulation of plant residues and their decomposition by molds and bacteria in the soil.

WAKSMAN (16) has explained the relatively constant carbonnitrogen ratio of the soil organic matter and its significance as follows:

"It could not be otherwise; were the carbon content too large in relation to the nitrogen, the soil would not be in a condition to support plant growth, as long as this excess lasted; the microorganisms using the carbon as a source of energy would assimilate every trace of available nitrogen that would otherwise be made available for the growth of higher plants. Were the nitrogen content too large, ammonia would be rapidly liberated and then transformed to nitrates and either leached out or assimilated by higher plants."

WAKSMAN has estimated the carbon-nitrogen ratio of fungus mycelia to be about 9 or Io, and that of bacteria about 4 or 5 . Undecomposed plant material has a ratio varying from 20 in legumes to 80 or more in wheat straw. The carbon-nitrogen ratio of the soil may thus be considered an index of the relative amounts of undecomposed plant residues, fungi, and bacteria present. Sievers and Holtz (I4) have called attention to the fact that virgin soils have a wide ratio and that under cultivation the ratio tends to become narrower, as illustrated by the following table:

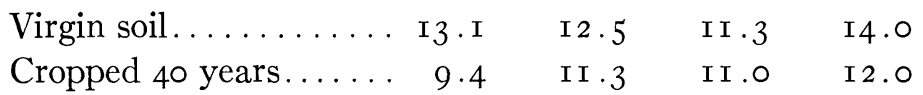


The carbon-nitrogen ratio in cultivated or fallowed soils, according to these investigators, tends to approach 9 as a minimum value. This is due mainly to the smaller supply of decomposable material returned to the soil each year, and probably to some extent to the more favorable conditions for decay in the cultivated soil.

Alway and McDole (2) have reported the carbon-nitrogen ratios in successive foot-sections of virgin soil at Lincoln to be I 2.0, I0.2, 9.5, 5.9, 6.0, and 5.4. In table II are presented the organic matter-nitrogen ratios and the corresponding carbon-nitrogen ratios of the several horizons of the Lancaster loam. The ratios decrease rapidly with increasing depth, and in this respect may be considered typical of normal upland prairie soil profiles. The narrower ratios at greater depths may be explained by the presence of relatively small quantities of root residues in proportion to relatively large quantities of the decomposition products of fungal and bacterial activity. BROWN and BENTON (5) have made a comprehensive study of the distribution of microorganisms in the prairie soils of Iowa. They have shown that the bacteria and actinomyces as a rule far outnumber the molds throughout the profile. The predominance of the bacteria and actinomyces tends to keep the carbon-nitrogen ratio low in those parts of the soil where the organic residues that form the food supply of the organisms are small in amount.

The organic matter-nitrogen ratios throughout the Wabash profile, shown in table II, are essentially those of surface soil. They appear to indicate that where the surface soil has accumulated organic matter and then been buried under fresh sediments, the organic matter so buried retains the characteristics of surface material for a long time. The explanation for such behavior is difficult to find. It may be tentatively suggested, without definite experimental proof applied to the conditions existing in these soils, that the surface type of organic matter contains a large proportion of lignins and ligninlike materials, non-nitrogenous substances which are resistant to decay. According to WAKSMAN and Iyer (I7), the lignins will combine with proteins, forming complexes that are highly resistant to decomposition, and which may be expected to persist in the soil unchanged for a long time. Decomposition would be especially slow in soils nearly saturated with water, as in the lower layers of the 
Wabash profile. Additional evidence to support this theory is found in the fact that these layers contain relatively large amounts of organic matter in comparison with the corresponding sections of upland soils. The Wabash profile contains I.24, I.44, and I.22 per cent of organic matter in the fourth, fifth, and sixth foot sections respectively, while the corresponding sections of loess soil at Lincoln were reported by Alway and MCDole (2) to contain $0.60,0.43$, and 0.40 per cent of organic matter.

\section{Summary}

I. A typical square meter of vegetation was selected in the upland, Andropogon scoparius prairie on Lancaster loam soil, near Lincoln, Nebraska, and another in the lowland, A. furcatus prairie on the Wabash clay loam soil of the floodplain of the Missouri River.

2. The surface soil was removed in 6-inch layers and the deeper soil in foot sections to the depth of root penetration; the roots and rhizomes were carefully removed by washing, and their dry weights, nitrogen contents, and organic contents determined.

3. Water content of soil and atmospheric factors affecting plant development were measured and rate of growth of the vegetation was determined. Root habits of the plants excavated were noted.

4. The soils varied so uniformly in texture, structure, and fertility with depth, that (except in buried surface layers) root distribution was of the usual type found for these species over a wide range of prairie soils.

5. In the Lancaster loam 60 per cent of the underground parts of the dominant grass was found in the surface 6 inches; the remainder of the root system was distributed to a depth of 4 feet. In the Wabash clay loam 68 per cent of the underground parts (6o per cent excluding rhizomes) was found in the surface 6 inches; the remainder of the root system extended to the depth of 7 feet and nearly to the water table.

6. The hygroscopic coefficient and moisture equivalent of each section of the soil profile were determined as indexes of the texture. The volume-weight of the soil in the undisturbed field condition was determined. From the volume-weight, specific gravity, and field moisture content at the time of sampling, it was possible to calculate 
the pore space, space occupied by water, and air space in each section of the soil.

7. Volume-weight in the Lancaster loam increased gradually from I.I 2 in the surface 6 inches, where an abundance of roots, rhizomes, and dead organic matter filled the soil, to 1.64 in the fourth foot, where both living roots and dead organic matter were relatively sparse.

8. Volume-weight in the Wabash clay loam increased gradually (except in buried surface soils) from $\mathrm{r} .05$ in the first 6 inches to I.33 in the seventh foot. This was accompanied by a gradual decrease in both living root materials and dead organic matter.

9. Pore space in the surface 6 inches of Lancaster loam constituted 57 per cent of the volume of the soil. On an average 25 per cent was occupied by water and 32 per cent by air. It decreased with depth to 39 per cent at 4 feet, where I9 per cent was occupied by water and 20 per cent by air.

Io. Pore space in the surface 6 inches of Wabash clay loam occupied 60 per cent of the soil volume. On an average 32 per cent was filled with water and 28 per cent with air. It decreased regularly with depth (except for buried surface layers) to about $5^{\mathrm{I}}$ per cent in the seventh foot, where water occupied 4I per cent and air only Io per cent.

II. The organic matter and nitrogen content of the roots in the upland soil were somewhat higher than in the lowland, especially in the surface 6 inches.

I 2. The composition of the rhizomes in the lowland was determined separately; their organic matter and nitrogen content were greater than in the roots, owing to the storage of food reserves.

I3. The percentage of organic matter and nitrogen in each layer of the soil was determined, and the weight of each per square meter of soil calculated.

14. The ratio of soil organic matter to nitrogen varied in the Lancaster loam from 20 in the surface soil to 8.3 in the fourth foot, a variation typical of upland prairie soils.

I 5. The ratio of organic matter to nitrogen in the Wabash clay loam showed variations corresponding to the variations in the organic content at different depths. This indicates that the strata 
of high organic content had accumulated a surface type of organic matter during intervals in the silting process by which the present soil has been built up.

I6. Except in the surface 6 inches of soil, there is an approximately linear relation between the amount of root material and the amount of soil organic matter in the various soil horizons.

I 7. In the surface soil the presence of a large amount of living rhizome and root material and the favorable conditions for the decomposition of dead organic matter increase the proportion of roots and rhizomes to soil organic matter.

I8. Roots and rhizomes constitute about one-tenth of the total organic matter in the surface 6 inches of soil; in the deeper sections the proportion decreases gradually from 3 to 4 per cent in the second 6 inches to I per cent in the fourth foot of the Lancaster soil, and 0.25 per cent in the seventh foot of the Wabash soil.

UNIVERSITY OF NEBRASKA

LiNCOLN, NEBRASKA

\section{LITERATURE CITED}

I. Alway, F. J., Kline, M. A., and McDole, G. R., Some notes on the direct determination of the hygroscopic coefficients. Jour. Agr. Res. Ir : I47-I66. I9I 7 .

2. Alway, F. J., and McDole, G. R., The loess soils of the Nebraska portion of the transition region. I. Hygroscopicity, nitrogen and organic carbon. Soil Sci. I:197-238. I916.

3. Association of Official Agricultural Chemists. Official and tentative methods of analysis. 3rd ed. p. 5. I930.

4. Biswell, H. H., and Weaver, J. E., Effect of frequent clipping on the development of roots and tops of grasses in prairie sod. Ecology I $4: 368-390$. I933.

5. Brown, P. E., and Benton, T. H., Microbiological studies of some typical Iowa soil profiles. Iowa Agr. Exp. Sta. Res. Bull. I32. I930.

6. FlORY, E. L., Comparison of the environment and some physiological responses of prairie vegetation and cultivated maize. (Unpublished.) I934.

7. Hougen, V. H., Structure of the Andropogon furcatus consociation and rate of growth compared with upland type of grassland. (Unpublished.) I933.

8. Meyer, A. H., Smies, E. H., Bushnell, T. M., Scarborough, R. J., Smith, C. W., Burn, R. R., and Spafford, R. R., Soil survey of Cass County, Nebraska. Field Operations of the Bureau of Soils. 19I3. 
9. Robinson, W. O., The determination of organic matter in soils by means of hydrogen peroxide. Jour. Agr. Res. 34:339-356. I927.

io. Russel, J. C., and Bulatkin, B., A procedure for the taking of surface and subsoil samples without disturbance of structure. (Unpublished.) I934.

II. RUSSEL, J. C., and BURR, W. W., Studies on the moisture equivalent of soils. Soil Sci. I9:25I-266. I925.

12. Russel, J. C., and Engle, E. B., The organic matter content and color of soils in the central grassland states. Proc. and Papers, Ist. Inter. Cong. Soil Sci. Commission 5:343-349. I927.

I3. Russel, J. C., and MCRuer, W. G., The relation of organic matter and nitrogen content to series and type in virgin grassland soils. Soil Sci. 24: $42 \mathrm{I}-45^{2}$. I 927 .

I4. Sievers, F. J., and Holtz, H. F., The significance of nitrogen in soil organic matter relationships. Wash. Agr. Exp. Sta. Bull. 206. I926.

15. Sprague, H. B., Root development of perennial grasses and its relation to soil conditions. Soil Sci. 36: 189-209. I933.

I6. WaKSMAN, S. A., Influence of microorganisms upon the carbon-nitrogen ratio in the soil. Jour. Agr. Sci. 14:555-562. 1924.

I7. Waksman, S. A., and Iyer, K. R. N., Contribution to our knowledge of the chemical nature and origin of humus. I. On the synthesis of the "humus nucleus." Soil Sci. 34:43-69. I932.

r8. Weaver, J. E., The ecological relations of roots. Carnegie Inst. Washington. Publ. 286. I9I9.

19. Weaver, J. E., and Fitzpatrick, T. J., The prairie. Ecol. Mon. 4: i i I-295. I934.

20. Weaver, J. E., and Himmel, W. J., The environment of the prairie. Cons. and Surv. Div. Univ. Nebr. Bull. 5. I93I. 